\title{
CRIMES DE SONEGAÇÃO FISCAL E A EXTINÇÃO DA PUNIBILIDADE
}

\author{
Hugo Brazioli Slivinskis \\ Ex-aluno da Faculdade de Direito da Universidade de \\ São Paulo. Advogado em São Paulo
}

Resumo:

$\mathrm{O}$ artigo principia com o conceito de sonegação fiscal e sua natureza jurídica, apresentando posteriormente o conceito, a evolução legislativa e o procedimento da representação fiscal, onde aborda inclusive a questão de o Ministério Público estar ou-não vinculado a ela para poder propor a denúncia.

A extinção da punibilidade pelo pagamento da exação antes do recebimento da denúncia é o tópico seguinte do artigo, que analisa a perspectiva legal do tributo ser ou-não considerado como pagamento para fins de extinção da punibilidade.

Abstract:

The article begins with the concept of tax evasion, as well as its juridic nature, presenting afterwards its legislative evolution and the procedure of the previous administrative fiscal inquest, addressing the question of whether the public attorney is restricted to it when bringing the formal charge before the court.

The extinction of liability to condemnation through payment of the excision before reception of the formal charge is the next topic of the article, which considers the legal perspective of this benefit, the moments when it may be invoked as well as the question of whether the stalled debt may be considered as a payment entailing the extinction of liability to condemnation.

Unitermos: sonegação fiscal; representação fiscal; extinção da punibilidade. 
Sumário:

Sumário:

1. Introdução; A. Conceito de sonegação fiscal e sua natureza jurídica; 2. Representação fiscal federal; A. Conceito; B. Evolução legislativa; C. Procedimento da representação fiscal; C1. Procedimento do Decreto n. 982/93; C2. Procedimento vigente; $\mathrm{C} 3$. Pré-requisito administrativo para a representação fiscal para fins penais; 3. Extinção da punibilidade; A. Perspectiva legal; B. Momentos para extinção da punibilidade; C. Parcelamento do débito; $\mathrm{C}$. Procedimento do parcelamento tributário federal; C2. Posições sobre o parcelamento e a extinção da punibilidade; 4. Sintese; 5. Bibliografia; Doutrina; Códigos e Leis; Jurisprudência.

\section{Introdução}

O presente estudo pretende observar alguns aspectos dos crimes de sonegação fiscal e seus assemelhados (arts. $1^{\circ}$ e $2^{\circ}$ da Lei n. 8.137/90) em relação à extinção da punibilidade.

Essas questões adquirem cada vez mais importância no mundo jurídico-financeiro de hoje, no qual, por exemplo, empresários acabam escolhendo adimplir a folha de funcionários ou os empréstimos bancários ao Fisco, postergando, desta forma, dolosamente, o recolhimento de tributos e contribuições sociais.

Pelas informações disponíveis nos sistemas e malhas da Secretaria da Receita Federal ${ }^{1}$ e pelo constante trabalho dos auditores-fiscais do Tesouro Nacional, esse comportamento, não-raro, culmina em auto de infração.

Lavrado o auto de infração e imputada a multa agravada, ou exigida posteriormente em processo administrativo, o devedor estará na iminência de sofrer ação penal pela prática de crime contra a ordem tributária, pelo impulso do Executivo, ou antes do término do processo administrativo e sem a necessidade de haver multa agravada quando o membro do Ministério Público entenda presentes os elementos para propor a ação penal.

1. O estudo não-ultrapassa a seara dos tributos administrados pela Secretaria da Receita Federal. 
Neste particular, o devedor poder-se-ia utilizar do instituto da extinção da punibilidade pelo pagamento dos débitos dos tributos ou das contribuições e seus acessórios até o momento imediatamente anterior ao recebimento da denúncia.

A questão do pagamento dos débitos tributários como causa extintiva da punibilidade adquire mais ênfase quando conjugada com o parcelamento, à medida que existem divergências e jurisprudências quanto à extinção ou-não da punibilidade, do pagamento integral e do parcelamento.

Ou seja, esse estudo coloca algumas questões que devem ser consideradas no momento em que o contribuinte decide tornar-se dolosamente devedor perante o Fisco.

A. Conceito de sonegação fiscal e sua natureza jurídica

A Lei n. 8.137/90 não-conceituou legalmente o termo sonegação fiscal; no entanto tal omissão legislativa não-prejudicou a clareza de seus dispositivos legais, uma vez que a técnica legislativa utilizada foi a de definir os crimes contra a ordem tributária como aqueles em que há a supressão ou redução de tributo ou contribuição social ou qualquer acessório mediante condutas descritas taxativamente nos incisos I a $\mathrm{V}$ do art. $1^{0}$ :

Art. $1^{\circ}$ Constitui crime contra a ordem tributária suprimir ou reduzir tributo ou contribuição social $e$ qualquer acessório mediante as seguintes condutas:

I omitir informação ou prestar declaração falsa às autoridades fazendárias;

II fraudar a fiscalização tributária, inserindo elementos inexatos, ou omitindo operação de qualquer natureza, em documento ou livro exigido pela lei fiscal;

III falsificar ou alterar nota fiscal, fatura, duplicata, nota de venda ou qualquer outro documento relativo a operação tributável;

IV elaborar, distribuir, fornecer, emitir ou utilizar documento que saiba ou deva saber falso ou inexato;

$V$ - negar ou deixar de fornecer, quando obrigatório, nota fiscal ou documento equivalente, relativa a venda 
de mercadoria ou prestação de serviço, efetivamente realizada, ou fornecê-la em desacordo com a legislação.

Pena: reclusão de 2 (dois) a 5 (cinco) anos, e multa.

Parágrafo único. A falta de atendimento da exigência da autoridade, no prazo de 10 (dez) dias, que poderá ser convertido em horas em razão da maior ou menor complexidade da matéria ou da dificuldade quanto ao atendimento da exigência, caracteriza infração prevista no inciso $V$."

Tendo a lei conceituado de maneira genérica o que seja sonegação fiscal, da melhor doutrina dimanou o entendimento que "sonegação fiscal é a ocultação dolosa, mediante fraude, astúcia ou habilidade do recolhimerto de tributo devido ao poder público" 2

A inteligência dessa definição está em aclarar que os crimes de sonegação fiscal são crimes materiais de dolo específico, ou seja, para que a conduta do contribuinte seja típica é necessário que o ato praticado aperfeiçoe o fim especial de lesar o Erário através da supressão ou redução de tributo ou, ainda, contribuição ou seus acessórios mediante as condutas específicas descritas.

O Superior Tribunal de Justiça, em recurso de habeas corpus, mostrou-se consentâneo com o entendimento supra ao acordar, por unanimidade; que "nos crimes contra a ordem tributária, definidos no art. $1^{\circ}$, incisos I e IV, da Lei $n$. 8.137, de 27 de dezembro de 1990, a consumação ocorre com a prestação da declaração falsa ou uso do documento falso perante as autoridades fazendárias, com o resultado ou efeito de suprimir ou reduzir tributo" ${ }^{3}$

$\mathrm{O}$ art. $2^{0}$ da lei definiu quais a condutas assemelhadas aos crimes de sonegação fiscal:

Art. $2^{\circ}$ Constitui crime da mesma natureza:

2. Legislação Penal Especial, Moraes e Smanio.

3. STJ, $6^{\circ} \mathrm{T}$ RHC n. 4.097/DF (9400342209), rel. min. Pedro Acioli, Diário da Justiça, 13 mar. 1995, p.5.316. 
I fazer declaração falsa ou omitir declaração sobre as rendas, bens ou fatos, ou empregar outra fraude, para eximir-se total ou parcialmente de pagamento de tributo;

II deixar de recolher, no prazo legal, valor de tributo ou de contribuição social, descontado ou cobrado, na qualidade de sujeito passivo de obrigação que deveria recolher aos cofres públicos;

III exigir, pagar ou receber para si ou para o contribuinte beneficiário qualquer percentagem sobre a parcela dedutivel ou deduzida de imposto ou de contribuição como incentivo fiscal;

IV deixar de aplicar, ou aplicar em desacordo com o estatuído, incentivo fiscal ou parcelas de imposto liberadas por órgão ou entidade de desenvolvimento;

$V$ - utilizar ou divulgar programa de processamento de dados que permita ao sujeito passivo da obrigação tributária possuir informação contábil diversa daquela que é, por lei, fornecida à Fazenda Pública.

Pena: detenção, de 6 (seis) meses a 2 (dois) anos, e multa.

Ao revés dos crimes de sonegação fiscal, os crimes assemelhados são crimes formais, não necessitando da produção de resultado, qual seja dano ao Erário, para consistirem conduta típica.

Em conformidade com o STJ, ao cotejar o inc. I do art. $2^{\circ} \mathrm{com} o$ inc. I do art. $1^{\circ}$ são definidas no art. $2^{\circ}$ "condutas fraudulentas, visando ao nãopagamento do tributo ou pagamento a menor" enquanto no artigo anterior o que se protege é "a formação do crédito tributário" 4

4. STJ, $6^{\circ}$ T RHC n. 5.123/SP (9500635836), rel. min. Luiz Vicente Cernicchiaro, Diário da Justiça, 17 mar. 97, p. 07.554 . 
Ou seja, por serem condutas fraudulentas, não exigindo o resultado do dano ao Erário, as condutas assemelhadas são mais facilmente tipificáveis do que os crimes de sonegação fiscal.

2. Representação fiscal federal

\section{A. Conceito}

A representação fiscal é uma peça dirigida ao Ministério Público Federal tendente a apurar os ilícitos praticados em detrimento da Fazenda Nacional ou que concorram ou contribuam para tal fim.

B. Evolução legislativa

No âmbito federal, até 11 de agosto de 1998, o início do trâmite, que culminava com a representação fiscal ao Ministério Público Federal, dava-se quando os auditores-fiscais do Tesouro Nacional, no exercício de suas atribuições, deparavam com os fatos que entendiam configurar os ilícitos mencionados nos incs. I a XXII do art. $1^{\circ}$ do Decreto n. 982/93:

"Art. $1^{\circ}$ Os auditores-fiscais do Tesouro Nacional, no exercício das atribuições de fiscalização, de lançamento ou de cobrança de tributos e contribuiçóes devidos à Fazenda Nacional, representarão, perante o secretário da Receita Federal, com cópia para o titular da unidade administrativa em que tenham exercício $e$ para o superintendente regional da Receita Federal, sempre que apurarem ilicitos que entendam configurar:

I apropriação indébita (art. 11 da Lei n. 4.357, de 16 de julho de 1964);

II - sonegação fiscal (art. $1^{\circ}$ da Lei n. 4.729, de 14 de julho de 1965);

III crime contra a ordem tributária (arts. $1^{\circ} \mathrm{e} 2^{\circ} \mathrm{da}$ Lei n. 8.137, de 27 de dezembro de 1990); 
IV contrabando ou descaminho (art. 334 do Código Penal);

$V$ falsificação de papéis públicos (art. 293 do Código Penal);

VI - petrechos de falsificação (art. 294 do Código Penal);

VII falsificação de documento público (art. 297 do Código Penal);

VIII certidão ou atestado ideologicamente falso (art. 301 do Código Penal);

IX resistência (art. 329 do Código Penal);

$X$ desobediência a ordem legal de funcionário público (art. 330 do Código Penal);

XI desacato (art. 331 do Código Penal);

XII - exploração de prestígio (art. 332 do Código Penal);

XIII corrupção ativa (art. 333 do Código Penal);

XIV comunicação falsa de crime (art. 340 do Código Penal);

XV auto-acusação falsa (art. 341 do Código Penal);

XVI falso testemunho e falsa perícia (art. 342 do Código Penal);

XVII coação no curso do processo (art. 344 do Código Penal);

XVIII fraude processual (art. 347 do Código Penal);

XIX favorecimento pessoal (art. 348 do Código Penal);

XX favorecimento real (art. 349 do Código Penal);

XXI sonegação de papel ou objeto de valor probatório (art. 356 do Código Penal);

XXII qualquer outro crime praticado em detrimento da Fazenda Nacional ou que concorra ou contribua para a sua consumação.

(...)" 
O Decreto n. 2.730/98 substituiu os incisos de I a XXII do Decreto supracitado por dois incisos, imprimindo maior propriedade à representação fiscal para fins penais ao diminuir seu elastério, a saber:

\section{"I crime contra a ordéem tributária tipificado nos} arts. $1^{\circ}$ ou $2^{\circ}$ da Lei n. 8.137, de 27 de dezembro de 1990;

II crime de contrabando ou descaminho.

As demais condutas foram alocadas lato sensu nos incisos do art. $1^{\circ}$ da Portaria n. 503/99, no entanto a representação de que trata esta norma é a representação para fins penais, e não a representação fiscal para fins penais, o que, de fato, aumentou a especificidade de ambas, à medida que possuem requisitos e elementos distintos a serem cumpridos, v. g., não se exigem mais para a representação penal as cópias das declarações de rendimentos dos últimos cinco anos das pessoas físicas e jurídicas responsáveis ou sob suspeita de envolvimento com 0 delito (inc. III e VII, art. $3^{\circ}$ Decreto n. 982/93).

Assim, pode-se dizer do acerto do Decreto n. 2.730/98 e da Portaria n. 503 de 17.05 .99 ao distinguirem a representação fiscal para fins penais e a representação para fins penais, tornando ambas mais eficientes.

C. Procedimento da representação fiscal

O Decreto n. 982/93, revogado expressamente pelo Decreto n. 2.730 , de 11 de agosto de 1998, estipulava detalhadamente as normas do trâmite da representação fiscal para fins penais. O decreto em vigor estabeleceu que o "secretário da Receita Federal disciplinará os procedimentos necessários para a execução".

A disciplina surgiu com a Portaria SRF n. 1.805, de 28 de agosto de 1998, que em seu art. $1^{\circ}$ estabeleceu que os auditores-fiscais do Tesouro Nacional formalizarão a representação fiscal perante o delegado ${ }^{6}$ da unidade administrativa

5. Art. $3^{\circ}$
6. Inspetor ou Agente. 
em que tenham tido exercício durante ação fiscal que culminou com lavratura de auto de infração de exigência de crédito tributário ou decorrente de apreensão de bens sujeitos a pena de perdimento, sempre que constatarem fatos que configurem em tese os delitos tipificados nos arts. $1^{\circ}$ e $2^{\circ}$ da Lei $n .8 .137 / 90$ ou crime de contrabando ou descaminho.

\section{C1. Procedimento do Decreto n. 982/93}

$\mathrm{Na}$ vigência desse decreto os auditores-fiscais do Tesouro Nacional representavam ao secretário da Receita Federal, enviando cópia ao delegado ${ }^{7}$ da unidade administrativa de seu exercício e ao superintendente regional da Receita Federal.

O secretário da Receita Federal, em cumprimento do art. $4^{\circ}$ encaminhava os autos do processo administrativo ao procurador geral da República, que analisava valorativamente os elementos da representação, podendo enviá-la ao Ministério Público Federal, para que este, se entendesse cabivel, propusesse a denúncia, ou remetê-la ao órgão da esfera executiva competente para complementar a instrução da representação fiscal, se vislumbrasse a necessidade de esclarecimentos, diligências ou documentos adicionais.

Neste particular, poder-se-ia dizer que a representação fiscal passava, antes de ser proposta a denúncia, por quatro juízos valorativos: do auditor-fiscal do Tesouro Nacional, do secretário da Receita Federal, do procurador geral da República e do membro do Ministério Público Federal.

\section{C2. Procedimento vigente}

O procedimento vigente regido pela Portaria n. 1805/98 inicia seu curso quando o auditor-fiscal do Tesouro Nacional constatar em tese as infrações tipificadas na Lei n. 8.137/90, na ocasião da lavratura de auto de infração decorrente da exigência de crédito tributário ou que resulte em apreensão de bens sujeitos ao perdimento (art. $1^{\circ}$ caput). 
Após a lavratura do auto de infração, a representação fiscal para fins penais é igualmente possível, só que caberá ao chefe da respectiva unidade administrativa, se não-impugnada a exigência, ou ao delegado de julgamento da Receita Federal competente para julgar o litígio, se impugnada a exigência (art. $2^{\circ}$ incs. I e II).

A representação fiscal de toda a forma deverá ser apensada ao processo administrativo, a fim de ser o contribuinte cientificado e até legalmente impelido a saldar seu débito, já que a inexistência dele, como veremos, extingue a punibilidade do infrator.

Ao revés da norma anterior, o procedimento da representação para fins penais atualmente é mais célere, consistindo no encaminhamento direto ao Ministério Público.

A simplicidade do procedimento foi acertadamente adotada pelo secretário da Receita Federal, pois sendo a objetividade jurídica dos crimes de sonegação fiscal a proteção ao Erário, é conveniente que ela se dê o mais rápido possível.

A celeridade do encaminhamento da representação fiscal para fins penais não-denota absolutamente impropriedade de siso, já que está adstrita ao encerramento do processo administrativo, aliás, como já prescrevia o decreto anterior.

Desta forma, é correta a ilação de que a portaria aperfeiçoou o procedimento anterior, dotando-o de maior tecnicismo ao atender com mais celeridade à proteção ao Erário.

C3. Pré-requisito administrativo para a representação fiscal para fins penais

Até o momento, a única forma apresentada para o início da ação penal referente aos crimes de sonegação fiscal foi a representação elaborada pela autoridade administrativa ao Ministério Público, que está vinculada ao término do procedimento administrativo, $e x$ vi do art. 83 da Lei n. 9.430/96:

Art. 83 A representação fiscal para fins penais relativa aos crimes contra a ordem tributária definidos nos arts. $1^{\circ}$ e $2^{\circ}$ da Lei n. 8.137, de 27 de dezembro de 1990, será encaminhada ao Ministério Público após 
proferida a decisão final, na esfera administrativa, sobre a exigência fiscal do crédito tributário correspondente.

Parágrafo único. As disposições contidas no 'caput' do art. 34 da Lei n. 9.249, de 26 de dezembro de 1995 , aplicam-se aos processos administrativos $e$ aos inquéritos e processos em curso, desde que não-recebida a denúncia pelo juiz."

É pertinente observar que essa condição de procedibilidade atinge somente o Executivo, não estando o parquet a ela vinculado, já que os crimes de sonegação se incluem no rol dos crimes de ação penal pública incondicionada.

Ou seja, se o membro do Ministério Público entender presentes os elementos necessários para propor a ação penal poderá fazê-lo desde logo, não sendo preciso aguardar o término do processo administrativo. Essa questão já foi amplamente questionada nas vias judiciais, sendo hoje pacífica a não-subordinação, como se vê pela seguinte ementa, com votação unânime:

STJ, TP ADIn 1.571, rel. min. Neri da Silveira, Diário da Justiça, 25 set. 98, p. 00011.

"Ação direta de inconstitucionalidade. 2. Lei $n$. 9430, de 27.12.1996, art. 83. 3. Argüição de inconstitucionalidade da norma impugnada por ofensa ao art. 129, I, da Constituição, ao condicionar a notitia criminis contra a ordem tributária 'a decisão final, na esfera administrativa, sobre a exigência fiscal do crédito tributário', do que resultaria limitar o exercicio da função institucional do Ministério Público para promover a ação penal pública pela prática de crimes contra a ordem tributária. 4. Lei n. 8137/1990, arts. $1^{\circ} \mathrm{e}$ $2^{\circ}$. 5. Dispondo o art. 83 da Lei n. 9430/1996 sobre a representação fiscal, há de ser compreendido nos limites da competência do Poder Executivo, o que significa dizer, no caso, rege atos da administração fazendária, prevendo o momento em que as autoridades competentes 
dessa área da Administração Federal deverão excaminhar ao Ministerio Publico Federal os expedientes contendo notitia criminis, acerca de delitos contra a ordem tributária, previstos nos arts. $1^{\circ}$ e $2^{\circ} d a$ Lei n. 8.137/1990. 6. Não cabe entender que a norma do art. 83 da Lei n. 9.430/1996 coarcte a ação do Ministério Público Federal, tal como prevista no art. 129, I, da Constituição, no que concerne à propositura da ação penal, pois, tomando o MPF, pelos mais diversificados meios de sua ação, conhecimento de atos criminosos na ordem tributária não fica impedido de agir, desde logo, utilizando-se, para isso, dos meios de prova a que tiver acesso. 7. 0 art. 83 da Lei n. 9.430/1996 não define condição de procedibilidade para a instauração da ação penal pública, pelo Ministério Público. 8. Relevância dos fundamentos do pedido não caracterizada, o que é bastante ao indeferimento da cautelar. 9.

Medida cautelar indeferida" 8

Assim, por já estar decidido, é pacífica a questão de que o Ministério Público não está vinculado ao término do processo administrativo para propor a denúncia dos crimes de sonegação, podendo ser formados sem nenhum óbice grupos especiais para tal fim.

3. Extinção da punibilidade

A. Perspectiva legal

8. No mesmo sentido: STJ, $5^{\mathrm{a}} \mathrm{T}$ HC 6.338/RS (9700680479), rel. min. José Arnando da Fonseca, Diário da Justiça, 31 ago. 98, p. 00109, STF, $2^{\circ} \mathrm{T}$ - HC n. 75.723/SP, Rel. Carlos Velloso, Diário da Justiça, 06 fev. 98, p. 05, STJ, 6 a T HC n. 6.409/MA, rel. min. Vicente Leal, Diário da Justiça, 09 nov. 98, p. 0171 e STJ, $6^{3}$ T RHC n. 4.663/SP (9500289415), rel. min. Vicente Leal, Diário da Justiça, 21 set. 98, p. 00232. 
A Lei n. 8.137/90, em seu art. 14, estipulava que o contribuinte ou funcionário público que promovesse o pagamento do tributo ou contribuição social, inclusive acessórios, antes do recebimento da denúncia, teria sua punibilidade extinta em relação aos crimes definidos nos arts. $1^{\circ}$ a $3^{\circ}$ da referida lei.

"Art. 14. Extingue-se a punibilidade dos crimes definidos nos arts. $1^{\circ}$ a $3^{\circ}$ quando o agente promover $o$ pagamento de tributo ou contribuição social, inclusive acessórios, antes do recebimento da denúncia."

Com a vigência da Lei n. 8.383, de 30 de dezembro 1991, o art. 14 supracitado foi expressamente revogado pelo art. 98, sendo que obviamente essa alteração, por ser prejudicial ao sujeito, não-retroagiu.

Art. 98 Revogam-se o art. 44 da Lei n. 4.131, de 3 de setembro de 1962, os $\$ \S 1^{\circ}$ e $2^{\circ}$ do art. 11 da Lei $n$. 4.357, de 16 de julho de 1964, o art. 2 da Lei n. 4.729, de 14 de julho de 1965, o art. 5 do Decreto-Lei n. 1.060, de 21 de outubro de 1969, os arts. 13 e 14 da Lei $n$. 7.713, de 1988, os incisos III e IV e os $\$ \S 1^{\circ}$ e $2^{\circ} \mathrm{do}$ art. 7 e o art. 10 da Lei $n$. 8.023, de 1990, o inciso III e parágrafo único do art. 11 da Lei n. 8.134, de 27 de dezembro de 1990 e 0 art. 14 da Lei n. 8.137, de 27 de dezembro de 1990 " (grifo do autor)

Essa posição legislativa foi novamente alterada pelo art. 34 da Lei $n^{\circ}$ 9.249, de 26 de dezembro 1995, que restaurou a extinção da punibilidade, inclusive, devido à retroatividade da lei mais benéfica aos fatos praticados neste ínterim legislativo.

Art. 34. Extingue-se a punibilidade dos crimes definidos na Lei n. 8.137/90 e na Lei n. 4.729/65, quando o agente promover o pagamento do tributo ou 
contribuição social, inclusive acessórios, antes do recebimento da denúncia."

Com essa atitude legislativa, tornou-se claro que a objetividade jurídica da ação penal dos crimes de sonegação fiscal tem por interesse principal aumentar a coercitividade no recolhimento do tributo e somente secundariamente punir o infrator no âmbito penal.

No entanto, poderia ter sido adotada política legislativa diversa, que não-concedesse o favor da extinção da punibilidade, o que por certo levaria ao resultado de inibir a prática das condutas típicas dos crimes de sonegação fiscal. Política legislativa, sem dúvida, mais eficaz na proteção do Erário, se se considerar que somente uma parte das infrações fiscais ultrapassa a barreira do desconhecimento.

Em resumo, pode-se dizer que a extinção da punibilidade pelo pagamento do tributo antes do oferecimento da denúncia vigorou de 27 (vinte e sete) de dezembro de 1990 até 30 (trinta) de dezembro de 1991, foi retroativa ${ }^{9}$ de 30 (trinta) de dezembro de 1991 a 26 (vinte e seis) de dezembro de 1995, data em que se tornou novamente incorporada a nosso ordenamento jurídico.

B. Momentos para extinção da punibilidade

O momento adequado para o pagamento do tributo ou contribuição social é anterior ao recebimento da denúncia, $e x$ vi do art. 34 da Lei n. 9.249/95 (ou anteriormente com $o$ art. 14 da Lei n. 8.137/90).

Neste particular, questionou-se se o pagamento do tributo posteriormente ao oferecimento da denúncia ensejaria o mesmo favor legal. $\mathrm{O}$ Judiciário manifestou-se negativamente em diversas oportunidades, pacificando a questão, como com as seguintes ementas.

STJ, $5^{\mathrm{a}}$ T HC 5.632/SP (9700149412), rel. min.

Edcon Vidgal, Diário da Justiça, 01 set. 97 p. 40.851.

9. A retroatividade da lei restringiu-se àqueles casos em que o pagamento do tributo havia sido feito antes da denúncia, pois esse é o momento adequado para a extinção da punibilidade. 
Ementa:

Penal. processual. retenção de contribuições previdenciárias. pagamento posterior ao recebimento da denúncia. extinção da punibilidade. impossibilidade. 'habeas corpus: 1. inadmissivel a extinção da punibilidade prevista na Lei n. 9.249/1995 se o pagamento atrasado das contribuiçôes previdenciárias retidas ilegalmente for feito após o recebimento da denúncia. 2. pedido indeferido."

STJ, $3^{\text {a }}$ T MC 1190/SC (9800062858), rel. min. Felix Fischer, Diário da Justiça, 11 mai. 98, p. 0131.

Ementa:

"Penal e processual penal. medida cautelar criminal. condenação pelo delito previsto no art. 95 , 'd' da Lei $n$. 8.212/91. medida provisória n. 1.571-7 de 24/10/97. parcelamento após o recebimento da denúncia. não há qualquer indicativo, no ordenamento jurídico, de que $o$ parcelamento após o início da 'persecutio criminis in iudicio' seja causa de extinção da punibilidade. ausente, portanto, o indispensável 'fumus boni iuris', que pudesse ensejar o excepcional efeito suspensivo ao recurso especial interposto. medida cautelar indeferida.

Questão controvertida é a que diz respeito à extinção da punibilidade com o parcelamento do débito tributário, que será analisada no item seguinte. 
C. Parcelamento do débito

O parcelamento de débitos para com a Fazenda Nacional é regulado basicamente pela Portaria-Conjunta n. 663/98 e pela Medida Provisória n. 1.770/99.

$\mathrm{O}$ art. 14 da Lei n. 8.137/90 estipulava que a extinção da punibilidade do contribuinte ou funcionário público ocorreria quando fosse promovido o pagamento do tributo ou contribuição social não recolhidos em virtude da prática de sonegação fiscal antes do recebimento da denúncia.

A redação, embora clara, gerou polêmica em torno do pagamento parcelado das referidas exações extinguirem ou-não a punibilidade.

Dentre as questões que se soergueram na doutrina e na jurisprudência, tornou-se pacífica a posição de que o parcelamento do débito, quando pago integralmente antes do recebimento da denúncia, extingue a punibilidade. No entanto, posições contrastantes foram sustentadas quando o pagamento do parcelamento estava em curso no momento em que a denúncia era recebida ou quando era interrompido antes de a denúncia ser recebida.

Ou seja, era necessário solver se o simples deferimento do parcelamento pelo Fisco equivaleria ao pagamento referido no art. 14 da Lei $\mathrm{n}$. $8.137 / 90$, extinguindo a punibilidade do agente, ou se seria necessário o pagamento integral do parcelamento para tanto.

Antes de apresentar a solução dada a essas questões, é pertinente explicitar o procedimento do parcelamento de débitos federais dos tributos administrados pela Secretaria da Receita Federal.

C1. Procedimento do parcelamento tributário federal

Como já foi colocado, as normas legais que disciplinam o procedimento do parcelamento são a Portaria-Conjunta n. 663/98 e a Medida Provisória n. 1.770/99.

A medida provisória estabelece que, ao formular o pedido de parcelamento, o devedor deverá comprovar o recolhimento correspondente à primeira parcela de seu débito, calculada em virtude do montante devido e da quantidade de parcelas que pretende obter. ${ }^{10}$ Assim, se há um débito de $\mathrm{R} \$$ 
1.000.000,00 (um milhão) e o número de parcelas pleiteado é de 25 (vinte e cinco), deverá ser recolhido aos cofres do Erário o valor de $\mathrm{R} \$ 40.000,00$ (quarenta mil).

Esse valor deverá ser recolhido mensalmente ao Fisco ${ }^{11}$ até que 0 parcelamento seja deferido, sob pena de indeferimento. ${ }^{12}$

Concedido o parcelamento, o valor antecipado será deduzido da consolidação da dívida e, se houver divergência entre 0 número de parcelas pleiteadas e o de deferidas, haverá o recálculo do valor das parcelas. ${ }_{i}^{13}$

A rescisão do parcelamento ocorre com a falta de pagamento de duas prestações, sendo vedado o reparcelamento, ${ }^{14}$ ou quando o devedor não-formaliza dentro do prazo, se necessário, garantia fidejussória ${ }^{15}$ ou, se necessário, não a substitui ou complementa. ${ }^{16}$

Exposto o procedimento básico do parcelamento, pode-se concluir que ele somente modifica o direito de recebimento do Fisco do montante da dívida, não constituindo novação da relação jurídica, o que pode ser comprovado pelo fato de o parcelamento não-estar arrolado entre as causas extintivas da obrigação tributária. ${ }^{17}$

C2. Posições sobre o parcelamento e a extinção da punibilidade

O Superior Tribunal de Justiça já manifestou que, se o parcelamento for iniciado antes do recebimento da denúncia e vier sendo cumprido regularmente até então, não há justa causa para a instauração da ação penal. ${ }^{18} \mathrm{~A}$ exemplo desse entendimento, pode-se citar a seguinte ementa:

11. Art. 11 da Medida Provisória n. $1.770 / 99$ e art. $5^{\circ}$ da Portaria n. 663/98.

12. Art. $6^{\circ}$ da Portaria n. $663 / 98$.

13. Art. 10 da Portaria n. $663 / 98$.

14. Art. 13, par. ún. da Medida Provisória n. 1.770/99.

15. Art. 16, inc. II c/c art. $24 . \S 2^{\circ}$ da Portaria n. 663/98.

16. Art. 16, inc. III c/c art. 25 da Portaria n. 663/98.

17. Art. 155 do Código Tributário Nacional.

18. STJ, $2^{\mathrm{a}}$ T- HC n. 2.538-5/RS - rel. min. Jesus Costa Lima. Diário da Justiça, Seção I, 9 maio 1994 - Ementário n. 10/619. 
STJ, $6^{\mathrm{a}} \mathrm{T}$ HC n. 6.409/MA, rel. min. Vicente Leal, Diário da Justiça, 09 nov. 98, p. 0171.

Ementa:

"A jurisprudência uniforme deste Tribunal tem proclamado o entendimento de que a concessão de pagamento parcelado de débito fiscal, deferido antes do oferecimento da denúncia, enseja a extinção da punibilidade, nos termos do art. 34 da Lei n. 9.249/95."

Em outra oportunidade, o Superior Tribunal de Justiça prolatou explicitamente o entendimento de que somente o parcelamento que está sendo corretamente adimplido tem o condão de extinguir a punibilidade, in verbis:

STJ, $5^{a}$ T RHC 6909/SP (9700740293), rel. min. José Dantas, Diário da Justiça, 02 mar. 98, p. 0123.

Ementa:

Extinção da punibilidade, ao dizer-se que, para esse efeito, o parcelamento do débito fiscal equivale ao pagamento, isso não se aplica no caso da inadimplência das prestações acordadas."

Em posição contrastante pronunciou-se o STF, entendendo que a comprovação regular do pagamento das primeiras parcelas tem o condão de extinguir a punibilidade, uma vez que, ao se referir a pagamento, o preceito legal não faz distinção de ser integral ou parcelado.

STF, inq. n. 763/DF, rel. min. Carlos Velloso, Diário da Justiça, Seção I, 3 nov. 1994, p. 29.733.

Ementa:

o parcelamento do débito, com prova regular do pagamento das primeiras parcelas, equivale à real 
promoção do pagamento, porque o próprio art. 14 não distingue se o promover é integral ou parcelado, bastante, pois tenha-se o ato concreto de pagar, e o parcelamento isso traduz, ainda que fracionado.

Data maxima venia ao entendimento do Supremo, a ratio legis, ao definir os crimes contra a ordem tributária, foi a de outorgar maiores garantias ao Erário para o recebimento do crédito tributário, assim não-parece sistematicamente escorreito admitir que o simples pagamento de algumas parcelas extinguiriam a punibilidade do devedor, que, em tese, já deveria ter recolhido a exação no prazo normal e teve todo o tempo da dilação probatória do processo administrativo para fazê-lo.

Posição teleologicamente acertada foi expressa pelo STJ, ao estabelecer que o parcelamento deverá ser interpretado como condição suspensiva da extinção da punibilidade. Neste mesmo sentido e considerando que o parcelamento, como já foi explicado, não constitui novação jurídica, mais sim simples postergação das condições de pagamento que não tem o condão de extinguir a punibilidade, o STJ teve o seguinte entendimento, expresso pela ementa abaixo:

STJ, $6^{\text {a }}$ T HC n. 7.231/DF. Rel. Min. Luiz Vicente Cernicchiaro, Diário da Justiça, 17 fev. 99, p. 0166.

Ementa:

RHC processual penal sonegação fiscal parcelamento da dívida - extinção da punibilidade Lei n. 8.137, de 27/12/90. Lei n. 8.383, de 30/12/91 extinção do crédito tributário (ctn, art. 156) a infração penal, como causa, gera relação jurídica entre o estado (sujeito ativo) e o agente (sujeito passivo). No crime tributário a sonegação fiscal atua como causa. O parcelamento do débito, quando permitido, repercute na relação jurídica, especificamente, no conteúdo, dado modificar o direito de recebimento do credor, em havendo parcelamento (acordo de vontades), enquanto 
não vencido o prazo das prestações, o crédito não é exigivel. o débito, pelo menos em parte, torna-se vincendo. o parcelamento não se confunde com a novação (esta implica substituição da relação jurídica, com mudança do devedor, do credor ou do objeto da prestação). o parcelamento, ao contrário, mantém a relação jurídica e repercute apenas nas condições do pagamento. o parcelamento não está arrolado entre as causas de extinção do crédito tributário (ctn, art. 156). impõe-se, também aqui, interpretação lógicosistemática; invoquem-se, ademais, os principios gerais das obrigaçôes, o parcelamento não é causa extintiva da obrigação tributária, todavia, sendo honrado, implica pagamento, assim, obtido o parcelamento, na vigência $e$ condições da Lei n. 8.137/90, mantém-se a relação jurídica constituída, não é afetada (decorrência do direito adquirido) pela Lei n. 8.383/91.

Em síntese, pode-se dizer que existem duas posições contrastantes: a do STJ, que entende que somente o pagamento integral do parcelamento extingue a punibilidade do agente, ficando neste ínterim suspensa a punibilidade do agente, e a do STF. que considera que o simples pagamento de algumas parcelas antes do recebimento da denúncia tem o efeito de extinguir a punibilidade do devedor.

Neste particular, acertadamente, manifesta-se a Portaria n. 1.805/98 ao preceituar que mesmo em caso de parcelamento a representação fiscal para fins penais será encaminhada ao Ministério Público Federal para que se promova a ação penal, adotando claramente a posição do STJ.

$$
\begin{aligned}
& \text { "Art. } 3^{\circ} \text { (...) } \\
& I I-(\ldots)
\end{aligned}
$$

$\S 2{ }^{\circ}$ Parcelado o crédito tributário, serão anexadas, por cópia, à representação as peças do auto de infração comprobatórias do ilícito ou dos ilícitos nela descritos, bem como as peças relativas ao parcelamento, e, no 
máximo em dez dias, será remetida pelos Delegados e Inspetores da Receita Federal ao órgão do Ministério Público competente para promover a ação penal."

\section{Síntese}

Ao explicitar alguns dos aspectos sobre a extinção da punibilidade em relação à prática de crimes de sonegação fiscal, pôde-se concluir que o conceito de sonegação fiscal foi definido implicitamente pela Lei n. 8.137/90, ao estabelecer quais são as condutas puníveis sob o título de crimes contra a ordem tributária, e, na esfera administrativa, a substituição do Decreto n. $982 / 93$ pelo Decreto n. 2.730/98 aumentou a propriedade da representação fiscal para fins penais, ao diminuir seu elastério, sendo que o procedimento desta, a partir da edição da Portaria n. 1.805/98, pelo secretário da Receita Federal, se tornou mais célere e mais comprometido em atender à proteção do crédito tributário ao Erário.

Em relação à extinção da punibilidade pelo pagamento do débito pôde-se verificar que a ratio legis principal é aumentar o grau de coercibilidade no recolhimento do tributo ou contribuição social, inclusive acessórios, pelo devedor e apenas secundariamente promover a ação penal.

No tocante ao parcelamento do débito como causa extintiva da punibilidade foi relevada a existência de posições jurisprudenciais divergentes, de um lado o STF. entendendo que o simples pagamento de algumas parcelas antes do recebimento da denúncia extinguem a punibilidade, e do outro o STJ, com a posição de que somente o pagamento total das parcelas extingue a punibilidade do devedor, sendo que nesse ínterim ocorre a suspensão da punibilidade.

Em suma, foram observados alguns aspectos dos crimes de sonegação fiscal em relação à extinção da punibilidade, sem, de forma alguma, pretender esgotar a matéria.

São Paulo, junho de 1999. 
5. Bibliografia.

\section{Doutrina:}

CORRÊA, Antonio (coord.). Crimes contra a ordem tributária. São Paulo: RT, 1995.

COSTA JÚNIOR, Paulo José da. Infrações tributárias e delitos fiscais. São Paulo: Saraiva, 1995.

MORAES, Alexandre de; SMANIO, Gianpaolo Poggio. Legislação penal especial. São Paulo: Atlas, 1999.

\section{Códigos e Leis:}

Código Tributário Nacional.

Jurisprudência:

STF $2^{\circ} \mathrm{T}$ HC n. 75.723/SP rel. min. Carlos Velloso, Diário da Justiça, 06 fev. 98, p. 05.

STJ, $3^{\mathrm{a}}$ T MC n. 1.190/SC (9800062858), rel. min. Felix Fischer, Diário da Justiça, 11 mai. 98, p. 0131.

STJ, $5^{\mathrm{a}}$ T HC n. 5.632/SP (9700149412), rel. min. Edcon Vidgal, Diário da Justiça, 01 set. 97, p. 40.851 .

STJ, $5^{\mathrm{a}}$ T HC n. 6.338/RS (9700680479), rel. min. José Arnando da Fonseca, Diário da Justiça, 31 ago. 98, p. 00109.

STJ, 5 $5^{\mathrm{a}}$ T RHC n. 6.909/SP (9700740293), rel. min. José Dantas, Diário da Justiça, 02 mar. 98, p. 0123.

STJ, $6^{\mathbf{a}}$ T HC n. 6.409/MA, rel. min. Vicente Leal, Diário da Justiça, 09 nov. 98, p. 0171.

STJ, $6^{\text {a }}$ T HC n. 6.409/MA, rel. min. Vicente Leal, Diário da Justiça, 09 nov. 98, p. 0171.

STJ, $6^{\text {a }}$ T HC n. 7.231/DF rel. min. Luiz Vicente Cernicchiaro, Diário da Justiça, 17 fev. 99, p. 0166.

STJ, $6^{\text {a }}$ T HC n. 7.231/DF. rel. min. Luiz Vicente Cernicchiaro, Diário da Justiça, 17 fev. 99, p. 0166.

STJ, $6^{\mathbf{a}} \mathrm{T}$ RESP 100005/CE (9600417644), rel. min. Vicente Leal, Diário da Justiça, 29 jun. 98, p. 0334. 
STJ, $6^{a}$ T - RHC n. 4.663/SP (9500289415), rel. min. Vicente Leal, Diário da Justiça, 21 set. 98 , p. 00232.

STJ, $6^{\text {a }}$ T RHC n. 4.663/SP (9500289415), rel. min. Vicente Leal, Diário da Justiça, 04 dez. 95, p. 42.138.

STJ, TP ADIn n. 1.571, rel. min. Neri da Silveira, Diário da Justiça, 25 set. 98, p. 00011. 